\title{
The influence of porcine blood by-products on laying hen performance, egg quality, and yolk mineral content ${ }^{*}$
}

\author{
J. Orda ${ }^{1}$, D. Jamroz, A. Wiliczkiewicz, J. Skorupińska \\ and J.K. Kubizna
}

\author{
Wrocław University of Environmental and Life Sciences, \\ Department of Animal Nutrition and Feed Quality \\ Chetmońskiego 38C, 51-630 Wrockaw, Poland
}

(Received 6 March 2011; revised version 14 December 2011; accepted 15 March 2012)

\begin{abstract}
Isa Brown hens were divided into five groups, each with 12 replications, i.e. cages with 3 birds each. The isoprotein and isoenergetic diets (about $160 \mathrm{~g}$ crude protein and $11.3 \mathrm{MJ} \mathrm{ME} / \mathrm{kg}$ ) differed in their contents of spray-dried porcine blood plasma (SDBP) or spray-dried blood cells (SDBC), which amounted to 2 or $4 \%$. Control birds were fed a diet containing plant proteins only. Laying performance and egg quality parameters were recorded during three periods of laying: between 2-10 weeks (57 days), 11-18 weeks (62 days), and between 19-24 weeks of life (62 days) to determine the effect of blood by-products during different laying phases. The young hens from the experimental groups produced significantly fewer eggs $(\mathrm{P}<0.05)$ in comparison with control birds. During successive periods, the differences in the performance indices among groups due to type of animal meal or its level were insignificant. Only the laying phase influenced the analysed performance parameters $(\mathrm{P}<0.01)$. A significantly higher egg weight was obtained in older hens. In relation to egg shell weight, thickness, and share in total egg weight, significant differences were recorded only in younger hens. Reduced shell weight and share were noted in eggs from hens fed diets with animal meals $(\mathrm{P}<0.01)$ as compared with eggs from control birds. It can be said that the use of blood cell meal (2 or $4 \%$ ) negatively $(\mathrm{P}<0.01)$ influenced egg shell indices and yolk colour as compared with control or SDBP groups. Other parameters were not affected. Inclusion of SDBC enhanced the deposition of $\mathrm{Mg}$ and $\mathrm{Mn}(\mathrm{P}<0.01)$ in egg yolk. No clear justification was found for the use of spray-dried blood by-products as an alternative amino acid and mineral source in laying hen diets.
\end{abstract}

KEY WORDS: laying hens, porcine blood by-products, performance, egg quality, yolk minerals

\footnotetext{
* Supported by the Ministry of Scientific Research and Information Technology, Project W 205 $07431 / 3344$

${ }^{1}$ Corresponding author: e-mail: dorota.jamroz@up.wroc.pl
} 


\section{INTRODUCTION}

Porcine blood meals have long been used in the diets for monogastric animals, especially for pigs. This feed has not been considered a component of feed mixtures for poultry, however. The high temperature used during the drying process leads to extensive denaturation of blood proteins and, therefore, decreases their digestibility in young animals (Batterham et al., 1986; Moughan et al., 1999; Marichal et al., 2000). Because of the ban on the use of raw materials of animal origin in animal nutrition, porcine blood by-products as a dietary component have become more important.

In comparison with fish meal, commonly used in feed mixtures for poultry, the composition of porcine blood by-products is characterized by a specific amino acid pattern. Spray-dried porcine blood plasma (SDBP) contains almost three times less Met (Owen et al., 1995), a lower amount of Lys, 2-3-time more Cys, and more Try, Ileu, Leu and Val (Jamroz et al., 2011). In contrast, spray-dried porcine blood cells (SDBC) are poor in Ileu (Orda et al., 1988; NRC, 1998; Kerr et al., 2004; Márquez et al., 2005; Amino News, 2006; Jamroz et al., 2011). The mineral composition of blood by-products is characterized by low contents of $\mathrm{Ca}$, $\mathrm{P}$ and $\mathrm{Mg}$ and relatively high concentration of some microelements (Jamroz et al., 2011). The high Na content results from technological procedures used in the production of spray-dried blood meal.

The specific properties of blood by-products and their biological activity have been described in numerous studies performed mainly on weaned pigs (Gatnau et al., 1989; Hansen et al., 1993; Van Dijk et al., 2001; DeRouchey et al., 2002). The use of plasma as an immune modulator improved the health status of piglets (Kats et al., 1994; Pierce et al., 2005; Moretó and Pérez-Bosque, 2009) and of dogs and cats (Rodriguez et al., 2007). Dietary plasma proteins reduced intestine growth and lamina propria cell density in very young pigs (Jiang et al., 2000; Nofrarias et al., 2006) and modified intestinal wall histology (King et al., 2008). Beneficial effects of blood globulins were found in early studies by Shahidi et al. (1984).

A very limited number of similar studies on the use of blood meal or spraydried blood products in poultry feeding (Orda et al., 1988; Mazurkiewicz et al., 1990; Bregendahl et al., 2005; Vasan et al., 2007) makes it almost impossible to estimate the nutritional value and biological effects of blood by-products obtained by modified technologies.

In a cycle of our investigations, spray-dried porcine blood plasma and cells produced by modified methods described by Jamroz et al. (2011) were included into broiler chicken diets. The nutritional value, including amino acid digestibility and mineral balance, was determined. The obtained data did not gave unambiguous results concerning the usefulness of these animal meals in the feeding of young 
birds. The great variability of amino acid and mineral contents in particular product batches available on the feed market was reported by Jamroz et al. (2011). Earlier studies have shown that blood by-products did not influence the concentration of fatty acids in egg yolk due to their low fat content (Orda et al., 2011).

The purpose of the presented study was to examine the nutritional value of spray-dried porcine blood by-products and their effects on laying hen performance, egg quality, and mineral content of yolk.

\section{MATERIAL AND METHODS}

\section{Animals, management and feeding}

Eighteen-week-old Isa Brown pullets were kept in battery cages and fed a mixture containing about $145 \mathrm{~g}$ of crude protein and 11.4 MJ ME $/ \mathrm{kg}$. After the first eggs were laid (at the age of 20 weeks), the hens' allocation to groups was corrected according to laying rate and body weight. The hens were randomly divided into five groups, each comprising 12 replications, i.e. cages with 3 hens per cage, and were fed experimental mixtures ad libitum (Table 1); free access to drinking water was provided. The environmental temperature varied in the range from 18 to about $25^{\circ} \mathrm{C}$ in the spring-summer period. The lighting programme was $14 \mathrm{~h}$ of light.

The isoprotein and isoenergetic diets (about $160 \mathrm{~g}$ crude protein and 11.3 MJ $\mathrm{ME} / \mathrm{kg}$ ) differed in their share of spray-dried porcine blood plasma (SDBP) or spray-dried blood cells (SDBC), which were added at a rate of 2 or $4 \%$. Control birds were fed the plant-based mixture containing only plant protein (Table 1). The characteristics of the animal meals are presented in Table 2. These meals were produced by Duda Bis Sosnowiec (Poland), according to the procedure described by Jamroz et al. (2011). The drying temperature of plasma ranged between $80-98^{\circ} \mathrm{C}$ at the start and $38-45^{\circ} \mathrm{C}$ in the final stage; for blood cells, a drying temperature of $120-130^{\circ} \mathrm{C}$ and $40^{\circ} \mathrm{C}$ was applied, respectively. $\mathrm{NaCl}$ was added during processing of animal meals, which affected the $\mathrm{Cl}$ and $\mathrm{Na}$ contents in both SDBP and SDBC. The diets were calculated on the basis of the analysed composition of feed components using simple linear optimization and repeated control of the diets.

\section{Laying performance}

Laying performance was recorded in three periods of laying: between 2-10 weeks (57 days), 11-18 weeks (62 days), and between 19-24 weeks (62 days) to determine the effect of blood by-products during different laying phases (age). 


\section{PORCINE BLOOD BY-PRODUCTS - LAYING HENS PERFORMANCE}

Table 1. Composition of diets for hens ${ }^{1}$

\begin{tabular}{|c|c|c|c|c|c|}
\hline \multirow{2}{*}{ Item } & \multirow{2}{*}{ Control } & \multicolumn{2}{|c|}{ SDBP $^{2}$} & \multicolumn{2}{|c|}{$\mathrm{SDBC}^{3}$} \\
\hline & & $2 \%$ & $4 \%$ & $2 \%$ & $4 \%$ \\
\hline \multicolumn{6}{|l|}{ Ingredients, $\mathrm{g} / \mathrm{kg}^{-1}$} \\
\hline maize & 150.0 & 150.0 & 150.0 & 150.0 & 150.0 \\
\hline wheat & 352.0 & 370.9 & 387.0 & 378.0 & 401.2 \\
\hline barley & 200.0 & 200.0 & 200.0 & 200.0 & 200.0 \\
\hline spray-dried blood plasma (SDBP) & - & 20.0 & 40.0 & - & - \\
\hline spray-dried blood cells (SDBC) & - & - & - & 20.0 & 40.0 \\
\hline rape oil & 17.0 & 13.1 & 10.0 & 12.3 & 8.5 \\
\hline soyabean oilmeal & 174.2 & 140.2 & 107.0 & 133.8 & 94.0 \\
\hline dicalcium phosphate & 15.0 & 15.0 & 15.1 & 15.0 & 15.1 \\
\hline limestone & 77.5 & 77.7 & 77.7 & 77.8 & 78.0 \\
\hline $\mathrm{NaCl}$ & 3.3 & 2.0 & 2.0 & 2.0 & 2.0 \\
\hline mineral-vitamin premix ${ }^{1}$ & 10.0 & 10.0 & 10.0 & 10.0 & 10.0 \\
\hline DL-methionine $(98 \%)$ & 1.0 & 1.1 & 1.2 & 1.1 & 1.2 \\
\hline $\mathrm{EM}, \mathrm{MJ} / \mathrm{kg}^{2}$ & 112.4 & 115.1 & 112.7 & 112.5 & 111.4 \\
\hline \multicolumn{6}{|l|}{ Analysed nutrients, $g \mathrm{~kg}^{-1}$} \\
\hline crude protein & 157.9 & 158.8 & 162.4 & 160.4 & 163.7 \\
\hline crude fibre & 31.2 & 30.3 & 29.3 & 30.2 & 29.1 \\
\hline $\mathrm{Ca}$ & 35.1 & 36.0 & 35.4 & 35.3 & 35.7 \\
\hline $\mathrm{P}$ available (calculated) & 3.5 & 3.5 & 3.5 & 3.5 & 3.5 \\
\hline $\mathrm{Mg}$ & 1.99 & 1.96 & 1.92 & 1.95 & 1.91 \\
\hline $\mathrm{Na}$ & 1.50 & 1.72 & 2.44 & 1.62 & 2.24 \\
\hline $\mathrm{Cl}$ & 14.4 & 16.5 & 16.4 & 19.9 & 23.1 \\
\hline \multicolumn{6}{|l|}{ Microelements, $\mathrm{mg} \mathrm{kg}^{-1}$} \\
\hline $\mathrm{Mn}$ & 96.26 & 95.64 & 94.98 & 95.61 & 94.91 \\
\hline $\mathrm{Cu}$ & 5.90 & 6.41 & 6.93 & 5.69 & 5.48 \\
\hline $\mathrm{Fe}$ & 550.13 & 558.37 & 566.80 & 573.07 & 596.20 \\
\hline $\mathrm{Zn}$ & 56.63 & 56.49 & 56.31 & 56.44 & 56.23 \\
\hline \multicolumn{6}{|l|}{ Amino acids, $\mathrm{g} \mathrm{kg}^{-1}$} \\
\hline Asp & 13.43 & 13.04 & 12.67 & 13.40 & 13.38 \\
\hline Thr & 4.28 & 4.65 & 5.03 & 4.33 & 4.39 \\
\hline Glu & 41.04 & 40.36 & 39.62 & 39.60 & 38.11 \\
\hline Cys & 2.74 & 2.97 & 3.20 & 2.69 & 2.64 \\
\hline Gly & 5.93 & 5.88 & 5.84 & 6.06 & 6.20 \\
\hline Val & 5.16 & 5.59 & 6.03 & 5.95 & 6.74 \\
\hline Met & 3.41 & 3.39 & 3.42 & 3.40 & 3.42 \\
\hline Ileu & 3.90 & 4.01 & 4.12 & 3.61 & 3.31 \\
\hline Leu & 11.09 & 11.39 & 11.71 & 12.02 & 12.96 \\
\hline Tyr & 3.91 & 4.13 & 4.35 & 3.79 & 3.67 \\
\hline Phe & 6.66 & 6.83 & 7.00 & 7.05 & 7.44 \\
\hline His & 2.89 & 3.04 & 3.19 & 3.71 & 4.53 \\
\hline Lys & 7.34 & 7.66 & 8.00 & 7.82 & 8.31 \\
\hline Try & 1.51 & 1.55 & 1.59 & 1.41 & 1.31 \\
\hline \multicolumn{6}{|c|}{ 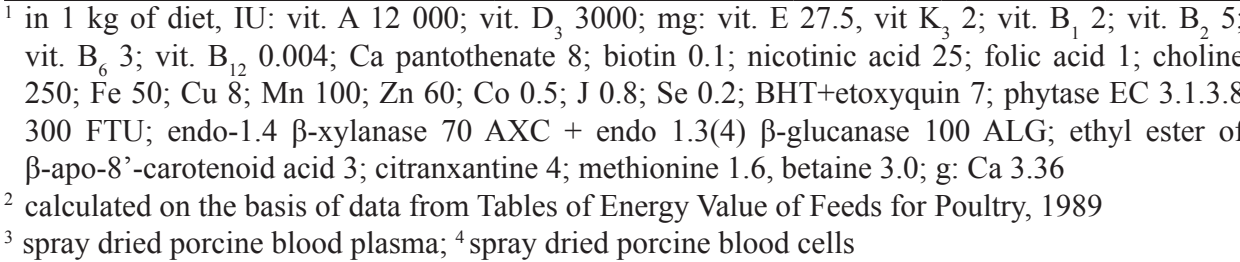 } \\
\hline
\end{tabular}


The number of eggs laid was recorded daily. All eggs from each cage (replicate were weighed). Also the feed intake, number of cracked eggs, and mortality of birds were registered weekly for cage-replicates.

Table 2. Amino acids and minerals contents in diets in spray dried porcine blood by-products

\begin{tabular}{lrr}
\hline Components & SDBP $^{1}$ & SDBC $^{2}$ \\
\hline Macroelements, $g / \mathrm{kg}^{-1}$ & & \\
$\mathrm{Ca}$ & 1.35 & 0.43 \\
$\mathrm{P}$ & 2.21 & 2.65 \\
$\mathrm{Mg}$ & 0.56 & 0.62 \\
$\mathrm{Na}$ & 36.72 & 31.74 \\
$\mathrm{Cl}$ & 62.3 & 17.20 \\
Microelements, $\mathrm{mg} / \mathrm{kg}^{-1}$ & & \\
$\mathrm{Mn}$ & 5.84 & 5.94 \\
$\mathrm{Cu}$ & 49.96 & 17.67 \\
$\mathrm{Fe}$ & 0.62 & 1.39 \\
Zn & 55.54 & 61.34 \\
crude protein, g kg-1 & 723.56 & 831.00 \\
Amino acids, $g / \mathrm{kg}^{-1}$ & & \\
$\mathrm{Asp}$ & 68.89 & 102.36 \\
Thr & 41.31 & 29.31 \\
Glu & 90.16 & 68.20 \\
Cys & 20.04 & 7.21 \\
Gly & 25.97 & 39.42 \\
Val & 45.49 & 67.36 \\
Met & 5.11 & 5.14 \\
Met + Cys & 25.15 & 12.35 \\
Ile & 23.22 & 6.07 \\
Leu & 66.45 & 106.29 \\
Tyr & 32.00 & 18.67 \\
Phe & 39.17 & 55.33 \\
His & 22.65 & 58.82 \\
Lys & 60.64 & 76.25 \\
\hline as & &
\end{tabular}

In the last week of each period, thirty eggs from each group were randomly sampled for determination of egg quality parameters using a PM $600 \mathrm{PX}$-processor apparatus (Technical Service and Supplies Ltd. York. England). Egg shell strength was measured using a ZWICK/Roell apparatus. Each measurement was repeated twice. Egg yolk colour was evaluated in the Hunter scale using a Konica Minolta apparatus (Chroma Meter CR 400, Japan) and compared with the Roche Yolk Color Fan scale. In the second and third control periods only 30 eggs per group were randomly sampled for chemical determination of $\mathrm{Ca}, \mathrm{P}, \mathrm{Mg}, \mathrm{Cu}, \mathrm{Mn}, \mathrm{Zn}$ and Fe content in yolk. Due to technical problems, the mineral content in yolk was not evaluated in the first experimental period.

All procedures were approved by the Local Ethics Commission for Experiments with Animals. 


\section{PORCINE BLOOD BY-PRODUCTS - LAYING HENS PERFORMANCE}

\section{Analytical methods}

The chemical compositions of the feed compounds and complete feed mixtures were determined according to standard methods (AOAC, 2005). The nitrogen content was evaluated using a Kjeltec 2300 Foss Tecator apparatus (Häganäs, Sweden); crude protein, by multiplying the nitrogen content by 6.25 ; crude fat, by ether extraction; crude fibre, by the Henneberg-Stohmann method using an Fibertec Tecator (Häganäs, Sweden) apparatus. Feed and egg yolk samples were mineralized with nitric acid $\left(\mathrm{HNO}_{3}\right)$ using a MarsX apparatus (CEM Corporation Matthews, USA). Phosphorus was analysed after previous mineralization with nitric acid and perchloric acid $\left(\mathrm{HClO}_{4}\right)$ according to the ammonium vanadomolybdate method using a Specol 11 spectrophotometer (Carl Zeiss, Jena) at a wave length of $470 \mathrm{~nm}$. Calcium and other minerals were determined by atomic absorption spectrophotometry using an AA 240 FS apparatus with SIPS 20 (Varian, Mulgrave, Australia).

Prior to the determination of amino acids, samples of components were hydrolysed with $6 \mathrm{M}$ hydrochloric acid $(\mathrm{HCl})$ for $24 \mathrm{~h}$ at $110^{\circ} \mathrm{C}$, then were separated according to the Moore (1963) and Moore and Stein method (1963). For the determination of sulphur amino acids, feed samples were oxidized $\left(0^{\circ} \mathrm{C}\right.$, $16 \mathrm{~h})$ with formic acid and hydrogen peroxide $\left(\mathrm{H}_{2} \mathrm{O}_{2}\right)(9: 1 / \mathrm{v}: \mathrm{v})$ and hydrolysed with $\mathrm{HCl}$ and then separated using an AAA 400 Ingos Analyzer (Prague, Czech Republic). For tryptophan determination, after alkaline hydrolysis with lithium hydroxide $(\mathrm{LiOH})\left(110^{\circ} \mathrm{C}, 16 \mathrm{~h}\right)$ and 4-dimethyl-aminobenzaldehyde (DMAB) the samples were examined colorimetrically at a wave length $590 \mathrm{~nm}$ according to the Landry and Delhaye (1992) procedure.

\section{Statistical analysis}

All data were evaluated statistically using one-, two-, or three-factorial ANOVA of the StatSoftStatistica ${ }^{\circledR}$ computer software (2005). The differences among parameters were tested according to the following statistical model:

or

$$
y i j=\mu+\alpha i+\text { eij (for differences between treatments) }
$$

$$
\begin{gathered}
\text { yjik }=\mu+\alpha i+\beta j+(\alpha \beta) i j+\text { eijk (for kind or inclusion level of animal meals) } \\
\text { yijkl }=\mu+\alpha i+\beta j+\gamma k+(\alpha \beta) i j+(\alpha \gamma) i k+(\beta \gamma) j k+(\alpha \beta \gamma) i j k+\text { eijkl }
\end{gathered}
$$

where: yij - yijk or yjikl, the variance associated with parameter $\alpha ; \mu$ - the overall mean; $\alpha \mathrm{i}$ - treatment effect; $\beta \mathrm{j}$, - the kind or share of meals in the diet; $\gamma$ - age of hens; $(\alpha \beta) i j$ - the interaction effect; and eij or eijk (eijkl) - an error term.

The individual measurements or averages for replications were treated as experimental units and differences between treatment averages were analysed 
for significance $(\mathrm{P}<0.01$ or $\mathrm{P}<0.05)$ using Tukey's test. All data are presented as average values and are accompanied by SEM (standard error) value.

\section{RESULTS}

\section{Performance indices}

The chemical composition of SDBP and SDBC used in experimental diets was typical for all 27 examined batches of such blood by-products. They were analysed and also used in an earlier study (Jamroz et al., 2011). The diets (groups) influenced only some of the analysed parameters. The type of blood by-products included in the diets for laying hens significantly $(\mathrm{P}<0.01, \mathrm{P}<0.05)$ affected the laying rate of young hens (2-10 weeks, one-factorial ANOVA), but in two-factorial (type or level of animal meals) ANOVA, no significant differences were found. In comparison with control hens fed the diet containing soyabean meal as the main protein source, the birds from the experimental groups produced significantly fewer eggs $(\mathrm{P}<0.05)$. In two-factorial (kind or level of animal meals) ANOVA, no significant differences in laying rate were found (Table 3). The insignificant

Table 3. Main effects of dietary treatments on performance in hens (2-24 week of laying)

\begin{tabular}{|c|c|c|c|c|c|c|c|}
\hline \multirow[b]{2}{*}{ Item } & \multirow[b]{2}{*}{$\begin{array}{c}\text { Egg weight } \\
\mathrm{g}\end{array}$} & \multirow{2}{*}{$\begin{array}{c}\text { Laying } \\
\text { rate } \\
\%\end{array}$} & \multirow{2}{*}{$\begin{array}{c}\text { Eggs per } \\
\text { hen } \\
\text { kg }\end{array}$} & \multicolumn{2}{|c|}{ Intake per 1 egg } & \multicolumn{2}{|c|}{ Intake per $1 \mathrm{~kg}$ of eggs } \\
\hline & & & & $\begin{array}{c}\text { feed } \\
\mathrm{g}\end{array}$ & $\begin{array}{c}\text { protein } \\
\mathrm{g}\end{array}$ & $\begin{array}{c}\text { feed } \\
\mathrm{kg}\end{array}$ & $\begin{array}{l}\text { protein } \\
\mathrm{g}\end{array}$ \\
\hline \multicolumn{8}{|l|}{ Treatments } \\
\hline control & 58.1 & 93.0 & 3.26 & 118.4 & 18.9 & 2.037 & 325.9 \\
\hline SDBP $2 \%$ & 59.1 & 93.7 & 3.34 & 116.9 & 18.7 & 1.978 & 316.4 \\
\hline SDBP $4 \%$ & 58.6 & 92.3 & 3.26 & 118.6 & 19.0 & 2.026 & 324.2 \\
\hline SDBC $2 \%$ & 58.7 & 93.7 & 3.32 & 117.1 & 18.7 & 1.994 & 319.1 \\
\hline SDBC $4 \%$ & 58.0 & 94.4 & 3.31 & 115.3 & 18.4 & 1.986 & 317.8 \\
\hline \multicolumn{8}{|l|}{ Type of meal } \\
\hline control & 58.1 & 93.0 & 3.26 & 118.4 & 18.9 & 2.037 & 325.9 \\
\hline SDBP & 58.8 & 93.0 & 3.30 & 117.7 & 18.8 & 2.002 & 320.3 \\
\hline SDBC & 58.4 & 94.0 & 3.31 & 116.2 & 18.6 & 1.990 & 318.5 \\
\hline \multicolumn{8}{|l|}{ Level of meal } \\
\hline control & 58.1 & 93.0 & $3.26^{\mathrm{a}}$ & 118.4 & 18.9 & 2.037 & 325.9 \\
\hline $2 \%$ & 58.9 & 93.7 & $3.33^{\mathrm{b}}$ & 117.0 & 18.7 & 1.986 & 317.8 \\
\hline $4 \%$ & 58.3 & 93.3 & $3.28^{\mathrm{ab}}$ & 116.9 & 18.7 & 2.006 & 321.0 \\
\hline \multicolumn{8}{|l|}{ Laying phase } \\
\hline 2-10 weeks & $55.3^{\mathrm{A}}$ & $95.2^{\mathrm{A}}$ & $3.00^{\mathrm{A}}$ & $111.3^{\mathrm{A}}$ & $17.8^{\mathrm{A}}$ & $2.013^{\mathrm{A}}$ & $322.1^{\mathrm{A}}$ \\
\hline 11-18 weeks & $59.3^{\mathrm{B}}$ & $96.2^{\mathrm{A}}$ & $3.53^{\mathrm{B}}$ & $116.0^{\mathrm{B}}$ & $18.6^{\mathrm{B}}$ & $1.958^{\mathrm{B}}$ & $313.3^{\mathrm{B}}$ \\
\hline 19-24 weeks & $61.0^{\mathrm{C}}$ & $88.8^{\mathrm{B}}$ & $3.35^{\mathrm{C}}$ & $124.4^{\mathrm{C}}$ & $19.9^{\mathrm{C}}$ & $2.041^{\mathrm{C}}$ & $326.6^{\mathrm{AS}}$ \\
\hline pooled SEM & 0.341 & 0.524 & 0.031 & 0.001 & 0.132 & 0.008 & 1.346 \\
\hline
\end{tabular}

within columns, for each main effect, means with different superscript letters are significantly different at: ${ }^{\mathrm{a}, \mathrm{b}} \mathrm{P}<0.05$; $^{\mathrm{A}, \mathrm{B}} \mathrm{P}<0.01$. All interactions are not significant 
effects of animal meal on performance parameters are why the obtained data are not presented in Tables.

In successive laying phases, the differences among treatments caused by type of animal meal or its levels, were not significant. Moreover, calculation of average performance parameters for three periods (in total 26 weeks) confirmed this statement (Table 3). Only laying phase (age of hens) influenced the analysed performance parameters $(\mathrm{P}<0.01)$. Significantly higher average egg weights were obtained in older hens. The best eggs production was recorded in the second period (11-18 weeks of laying).

The feed intake calculated per egg or per kg of eggs was not modified by the diets containing blood by-products in comparison with traditional diets with soyabean meal.

The health status of birds was very good. Only single hens were removed from the experiment due to health reasons, however, no effects of diets were observed.

\section{Egg characteristics}

In egg shell weight, thickness, and share in overall egg weight, significant differences were noted in young hens (Period 1). Reduced weight and share of shell was noted in eggs from hens fed experimental diets $(\mathrm{P}<0.01)$ as compared with control birds. Reduced yolk colour expressed in the Roche scale $(\mathrm{P}<0.01)$ was observed in eggs from hens fed diets with blood by-products (Table 4).

Reduced shell parameters were recorded in eggs from older birds (Period 2) and only in the group of birds fed the mixture containing 4\% SDBC, whereas this parameter was the best in the SDBP treatment. The intensity of yolk colour was better in controls than in eggs from other groups.

In the third period of laying, the egg shell share in egg weight was significantly improved in experimental treatments $(\mathrm{P}<0.05)$, however, yolk colour was still the best in eggs from the control group.

Average values for analysed egg features (Table 4) indicate an unfavourable influence of $4 \%$ blood cell meal on egg weight, egg shell thickness, and yolk colour expressed in the Roche Color Fan Scale. On the basis of the obtained data it can be stated that the use of SDBC $(2$ or $4 \%)$ negatively $(\mathrm{P}<0.01)$ influenced egg shell indices and yolk colour as compared with control or SDBP-groups. Other parameters were not affected. 


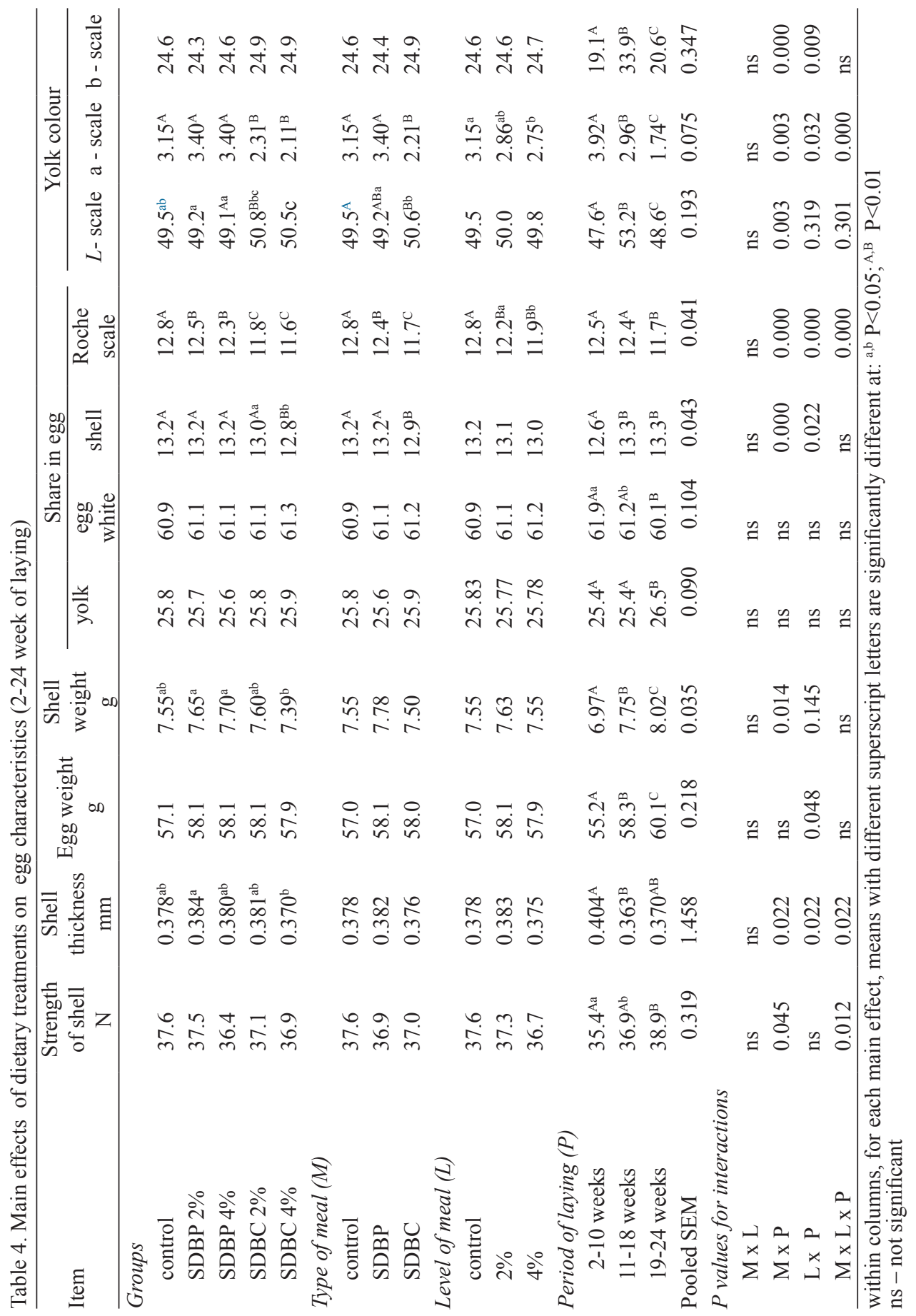




\section{PORCINE BLOOD BY-PRODUCTS - LAYING HENS PERFORMANCE}

\section{Mineral content in egg yolk}

The contents of minerals in egg yolk were analysed in the second and third period of laying. Inclusion of blood by-products into the diets (Period 2) significantly influenced Mn deposition in yolk only (as determined by twofactorial ANOVA); although the differences between treatments in the mineral content of yolk ( $\mathrm{P}, \mathrm{Mg}, \mathrm{Cu}, \mathrm{Zn}, \mathrm{Mn}, \mathrm{Fe}$ ) calculated by one-factorial ANOVA, were significant, no regular pattern was found. Similar results were noted in the third laying period. Significantly lower amounts of $\mathrm{Ca}, \mathrm{P}$ and $\mathrm{Mg}$ in yolk were found when SDBC meal was included in the diets.

Average values calculated for both laying periods (Table 5) indicate that inclusion of SDBC enhanced deposition of $\mathrm{Mg}, \mathrm{Mn}(\mathrm{P}<0.05)$, and $\mathrm{Fe}$ in egg yolk $(\mathrm{P}<0.01)$. Despite numerous significant differences in the mineral content of egg yolk caused by experimental factors, it was difficult to find a clear tendency among such diverse results.

Table 5 Main effects of dietary treatments on mineral content in yolk (10-24 week of laying)

\begin{tabular}{|c|c|c|c|c|c|c|c|}
\hline \multirow{2}{*}{ Item } & \multicolumn{2}{|c|}{$\mathrm{g} \mathrm{kg}^{-1}$} & \multicolumn{5}{|c|}{$\mathrm{mg} \mathrm{kg}^{-1}$} \\
\hline & $\mathrm{Ca}$ & $\mathrm{P}$ & $\mathrm{Mg}$ & $\mathrm{Cu}$ & $\mathrm{Mn}$ & $\mathrm{Zn}$ & $\mathrm{Fe}$ \\
\hline \multicolumn{8}{|l|}{ Groups } \\
\hline control & 1.15 & 4.35 & 178.1 & 2.19 & $3.73^{\mathrm{AB}}$ & 47.6 & 92.9 \\
\hline SDBP $2 \%$ & 1.19 & 4.59 & 157.9 & 2.19 & $3.66^{\mathrm{A}}$ & 51.3 & 191.6 \\
\hline SDBP $4 \%$ & 1.10 & 4.26 & 151.0 & 2.26 & $3.56^{\mathrm{A}}$ & 46.9 & 93.4 \\
\hline SDBC $2 \%$ & 1.10 & 4.24 & 139.3 & 2.37 & $3.90^{\mathrm{AB}}$ & 49.2 & 98.7 \\
\hline $\mathrm{SDBC} 4 \%$ & 1.13 & 4.35 & 120.8 & 2.20 & $4.32^{\mathrm{B}}$ & 49.5 & 98.7 \\
\hline \multicolumn{8}{|l|}{ Type of meal (M) } \\
\hline control & 1.15 & 4.35 & $178.1^{\mathrm{A}}$ & 2.19 & $3.73^{\mathrm{AB}}$ & 47.6 & $92.9^{\mathrm{a}}$ \\
\hline SDBP & 1.14 & 4.43 & $154.5^{\mathrm{AB}}$ & 2.22 & $3.61^{\mathrm{A}}$ & 49.1 & $97.5^{\mathrm{b}}$ \\
\hline $\mathrm{SDBC}$ & 1.11 & 4.30 & $130.1^{\mathrm{B}}$ & 2.28 & $4.11^{\mathrm{B}}$ & 49.4 & $98.7^{\mathrm{b}}$ \\
\hline \multicolumn{8}{|l|}{ Level of meal (L) } \\
\hline control & 1.15 & 4.35 & $178.1^{\mathrm{Aa}}$ & 2.19 & 3.73 & 47.6 & $92.9^{\mathrm{A}}$ \\
\hline $2 \%$ & 1.14 & 4.42 & $148.6^{\mathrm{ABb}}$ & 2.28 & 3.78 & 50.2 & $100.1^{\mathrm{B}}$ \\
\hline $4 \%$ & 1.11 & 4.31 & $135.9^{\mathrm{B}}$ & 2.23 & 3.94 & 48.2 & $96.06^{\mathrm{AB}}$ \\
\hline \multicolumn{8}{|l|}{ Laying phase $(P)$} \\
\hline 11-18 weeks & $1.23^{\mathrm{A}}$ & $4.69^{\mathrm{A}}$ & $189.1^{\mathrm{A}}$ & $2.26^{\mathrm{A}}$ & $4.06^{\mathrm{A}}$ & $45.8^{\mathrm{A}}$ & $99.4^{\mathrm{A}}$ \\
\hline 19-24 weeks & $1.04^{\mathrm{B}}$ & $4.03^{\mathrm{B}}$ & $109.7^{\mathrm{B}}$ & $2.22^{\mathrm{B}}$ & $3.61^{\mathrm{B}}$ & $52.1^{\mathrm{B}}$ & $94.7^{\mathrm{B}}$ \\
\hline pooled SEM & 0.19 & 0.052 & 6.83 & 0.038 & 0.075 & 0.794 & 1.039 \\
\hline \multicolumn{8}{|c|}{$P$ value for interactions } \\
\hline$M \times L$ & ns & 0.004 & ns & $\mathrm{ns}$ & 0.043 & ns & ns \\
\hline $\mathrm{M} \times \mathrm{P}$ & ns & ns & ns & ns & ns & ns & ns \\
\hline$L \times P$ & ns & 0.011 & ns & ns & 0.003 & ns & ns \\
\hline $\mathrm{M} \times \mathrm{L} \times \mathrm{P}$ & ns & 0.006 & 0.013 & ns & 0.020 & ns & 0.006 \\
\hline
\end{tabular}

within columns, for each main effect, means with different superscript letters are significantly different at: ${ }^{a, b} \mathrm{P}<0.05$; ${ }^{\mathrm{A}, \mathrm{B}} \mathrm{P}<0.01$ 


\section{DISCUSSION}

Nutritional utilization of animal slaughter by-products is not fully recognized yet. The potential threat for human and animal health has caused a ban on the use of meat- and meat-bone meals and other animal origin by-products, especially from ruminants, in animal nutrition. The use of some animal origin feed materials in the diets for monogastric animals is now permitted. For instance, porcine blood by-products are frequently introduced into diets for weaned pigs. Despite beneficial effects on animal health, the question related to the usefulness of blood by-products in poultry feeding has still not been resolved. The important problem that should always be considered is the quality of these feedstuffs resulting from instability of the chemical composition of raw materials, i.e. blood, used in wasteless processing technologies and from the applied temperature and drying technique (Donkoh et al., 1999; Moughan et al., 1999; Marichal et al., 2000; Pierce et al., 2005).

The anticipated beneficial effects of blood by-products containing specific active proteins and microelements introduced into pig diets (Shahidi et al., 1984; Cain et al., 1992; Coffey and Cromwell, 1995; De Rodas et al., 1995; Goodfredson-Kisić and Johnson, 1997) were not confirmed in our investigations. The specific amino acids and the mineral composition of SDBP and SDBC did not improve the health, performance, or some biochemical indices of blood and histological pictures of the broiler intestine wall (Jamroz et al., 2011). When blood cell meal was used, the results were even worse than in control animals. The same unfavourable effects have also been reported after using blood meal in investigations by Donkoh et al. (1999).

The lack of a positive effect was also observed in the current study carried out with laying hens. The beneficial effects of the immunoglobulins present in SDBP or SDBC observed by Rodriguez et al. (2007) and Moretó and Pérez-Bosque (2009) were not seen, despite the very good health status of the birds in all groups.

In the presented study, the type of blood products did not influence basal performance. As signalized by Kerr et al. (2004), Tyus et al. (2009) and Jamroz et al. (2011), the deficit of isoleucine in blood cells did not significantly affect laying parameters. In successive periods, some of the differences between all treatments and for experimental factors (type and level of spray-dried blood by-products) were statistically insignificant. Only the age of hens (laying phase) significantly $(\mathrm{P}<0.01)$ influenced laying rate and feed conversion. This statement is generally well-known and has been confirmed in our earlier studies (Jamroz et al., 2003) and other investigations (Bozkurt et al., 2004).

Addition of SDBC meal in the current studies significantly decreased egg shell weight, its thickness $(\mathrm{P}<0.01)$, and also the share of shell in the mass of eggs laid 
by young hens. The differences in these parameters among groups depending on the type of animal meal used found in older birds followed no pattern. Nonetheless, the average values calculated for 26 weeks of the whole experimental period did not confirm a negative effect of feeding SDBC meal on egg shell characteristics when compared with the control group. The high $\mathrm{Na}$ level in mixtures containing $4 \%$ of SDBP or SDBC can influence mineral homeostasis in hens and the mineral composition of egg content. No publications in the available literature were found that could be helpful in explaining the specific effects of these animal meals on egg shell quality.

A distinct decrease in the colour of yolks $(\mathrm{P}<0.01)$ in eggs from hens fed SDBC was found in the conducted experiment. This was observed in the first and third laying periods and for the entire experiment ( 26 weeks). The explanation of these findings is difficult because the basal chemical characteristics of the mixtures used in feeding the hens were very similar. It can only be supposed that some specific ingredients of blood cell meal (i.e. blood pigment, antioxidants, or other ingredients) could be involved, e.g., in inhibiting the metabolism of carotenoids or their passage into egg yolk (Gomez-Juárez et al., 1999). No publications were found in the literature relating to this specific response.

Despite the similar mineral composition of the diets used, except for the $\mathrm{Na}$ level, the variability among groups in the concentration of minerals in egg yolks was significant for $\mathrm{P}, \mathrm{Mg}, \mathrm{Fe}$ and $\mathrm{Mn}$ (in the second laying period) and for $\mathrm{P}, \mathrm{Mg}$, $\mathrm{Mn}$ in the third period. Spray-dried blood cell meal significantly $(\mathrm{P}<0.01)$ reduced the $\mathrm{Mg}$ and increased the $\mathrm{Mn}$ content in egg yolk as compared with controls (three-factorial ANOVA). An insignificantly higher $\mathrm{Zn}$ content in yolk was found in treatments using diets containing animal meals in the second laying period. Finally, on the basis of these observations related to both laying periods and experimental factors it could be stated that the inclusion of SDBC meal into diets for laying hens significantly decreased the $\mathrm{P}$ and $\mathrm{Mg}$ level in yolk as compared with the concentration of these minerals in eggs from the control group.

The diverse results obtained in this study cannot be adequately explained on the basis of the specific influence of blood by-products. No clear justification was established for the use of spray-dried blood by-products as an alternative amino acid and mineral source in laying hen feeding. The effects of the treatments cannot serve as a recommendation for the use of spray-dried porcine blood plasma and blood cells in laying hen feeding.

\section{CONCLUSIONS}

In summary, the results obtained in the presented study cannot serve as a recommendation for the use of spray-dried porcine blood plasma (SDBP) and 
blood cells in diets for laying hens. It should also be stated that the use of spraydried blood cell (SDBC) meal $(2$ or $4 \%)$ negatively $(\mathrm{P}<0.01)$ influenced egg shell indices and yolk colour as compared with controls or SDBP groups. Other parameters were not affected. Inclusion of SDBC enhanced the deposition of $\mathrm{Mg}$, $\mathrm{Mn}$ and $\mathrm{Fe}(\mathrm{P}<0.01, \mathrm{P}<0.05)$ in egg yolk.

\section{REFERENCES}

Amino News ${ }^{\mathrm{TM}}$, 2006. D egussa Feed Additives

AOAC, 2005. Association of Official Analytical Chemists, Official Methods of Analysis. 17 $7^{\text {th }}$ Edition. Arlington, VA

Batterham E.S., Lowe R.F., Darnell R.E., Major E.J., 1986. Availability of lysine in meat meal, meat and bone meal and blood meal as determined by the slope-ratio assay with growing pigs, rats and chicks and by chemical techniques. Brit. J. Nutr. 55, 427-440

Bozkurt M., Alçiçek A., Çabuk M., 2004. The effect of dietary inclusion of meat and bone meal on the performance of laying hens at old age. S. Afr. J. Anim. Sci. 34, 31-36

Bregendahl K., Ahn D.U., Trampel D.W., Campbell J.M., 2005. Dietary spray-dried bovine plasma protein improves growth performance and breast-meat yield of broilers raised in a highantigen environment. Iowa State University, Animal Industry. Report R 2019

Cain C., Gatnau R., Arentson R., Zimmerman D., 1992. Effects of spray-dried porcine plasma on intestinal function and morphology in weanling pigs. Iowa State University. Swine Report ASL-941, 7-10

Coffey R.D., Cromwell G.L., 1995. The impact of environment and antibacterial agents and the growth response of early weaned pigs to spray dried porcine plasma. J. Anim. Sci. 73, 25322539

De Rodas B.Z., Sohn K.S., Maxwell C.V., Spicer L.J., 1995. Plasma protein for pigs weaned at 19 to 24 days of age: effect on performance and plasma, insulin like growth factor I, growth hormone, insulin and glucose concentration. J. Anim. Sci. 73, 3657-3665

DeRouchey J.M., Tokach M.D., Nelseen J.L., Goodband R.D., Dritz S.S., Woodworth J.C., James B.W., 2002. Comparison of spray-dried blood meal and blood cells in diets for nursery pigs. J. Anim. Sci. 80, 2879-2886

Donkoh A., Atuahene C.C., Anang D.M., Ofori S.K., 1999. Chemical composition of solar-dried blood meal and its effect on performance of broiler chickens. Anim. Feed Sci. Tech. 81, 299307

European Tables of Energy Values of Feeds For Poultry Feedstuffs, 1989. $3^{\text {rd }}$ Edition. WPSA, Wageningen (the Netherlands)

Gatnau R., Raul R.S., Zimmerman D.R., 1989. Spray dried porcine plasma (SDPP) as a source of protein for weanling pigs. J. Anim. Sci. 67, Suppl. 1, 244 (Abstr.)

Gómez-Juárez C., Castellanos R., Ponce-Noyola T., Calderón-Salinas V., Figueroa J., 1999. Functional properties of globin protein obtained from bovine blood by decolorization of the red cell fraction. J. Sci. Food Agr. 79, 793-796

Goodfredson-Kisić J.A., Johnson D.E., 1997. A bioassay used to identify the active fraction of spray-dried porcine plasma. J. Anim. Sci. 75, 195 (Abstr.)

Hansen J.A., Nelseen S.L., Goodband R.D., Weeden T.L., 1993. Evaluation of animal protein supplements in diets of early-weaned pigs. J. Anim. Sci. 71, 1853-1862 


\section{PORCINE BLOOD BY-PRODUCTS - LAYING HENS PERFORMANCE}

Jamroz D., Orda J., Skorupińska J., Wiliczkiewicz A., Wertelecki T., Żyłka R., Klünter A.-M., 2003. Reaction of laying hens to low phosphorus diets and addition of different phytase preparations. J. Sci. Food Agr. 12, 95-100

Jamroz D., Wiliczkiewicz A., Orda J., Skorupińska J., Słupczyńska M., Kuryszko J., 2011. Chemical composition and biological value of spray dried porcine blood by - products and bone protein hydrolysate for young chickens. Brit. Poultry Sci. 52, 589-605

Jiang R., Chang X., Stoll B., Fan M. Z., Arthington J., Weaver E., Campbell J., Burrin D.G., 2000. Dietary plasma protein reduces small intestinal growth and lamina propria cell density in early weaned pigs. J. Nutr. 130, 21-26

Kats L.J., Nelssen J.L., Tokach M.D., Goodband R.D., Weeden T.L., Dritz S.S., Hansen J.A., Friese K.G., 1994. The effects of spray-dried blood meal on growth performance of early - weaned pig. J. Anim. Sci. 72, 2860-2869

Kerr B.J., Kidd M.T., Cuaron J.A., Bryant K.L., Parr T.M., Maxwell C.V., Weaver E., 2004. Utilization of spray-dried blood cells and crystalline isoleucine in nursery pig diets. J. Anim. Sci. 82, 2397-240

King M.R., Morel P.C.H., Pluske J.R., Hendriks W.H., 2008. A comparison of the effects of dietary spray-dried bovine colostrum and animal plasma on growth and intestinal histology in weaner pigs. Livest. Sci. 119, 167-173

Landry J., Delhaye S., 1992. Determination of tryptophan in feedstuffs - comparison of two methods of hydrolysis prior to HPLC analysis. J. Sci. Food Agr. 58, 438-441

Marichal M.D.J., Carriquiry J.M., Pereda M., San Martín R., 2000. Protein degradability and intestinal digestibility of blood meals: comparison of two processing methods. Anim. Feed Sci. Tech. 88, 91-101

Márquez E., Brancho M., Archile A., Rangel L., Benítez B., 2005. Proteins, isoleucine, lysine and methionine content ofbovine, porcine and poultry blood and their fractions. Food Chem. 93, 503-505

Mazurkiewicz M., Jamroz D., Bartczak R., Gaweł A., 1990. The influence of Livex on the development and state of health of growing pheasants (in Polish). Med. wet. 46, 35-37

Moore S., 1963. On the determination of cysteine as cysteic acid. J. Biol. Chem. 238, 235-237

Moore S., Stein N.H., 1963. Discussion of classic method of acids hydrolysis. Method. Enzymol. 6.819

Moretó M., Pérez-Bosque A., 2009. Dietary plasma proteins, the intestinal system, and the barrier functions of the intestinal mucosa. J. Anim. Sci. 87, 92-100

Moughan P.J., Dong G.Z., Pearson G., Wilkinson B.H.P., 1999. Protein quality in blood meal, II, The effect of processing on in vivo nitrogen digestibility in rats, protein solubility and FDNBavailable lysine. Anim. Feed Sci. Tech. 79, 309-320

Nofrarías M., Manzanilla E.G., Pujols J., Gilbert X., Majó N., Segalés J., Gasa J., 2006. Effects of spray-dried porcine plasma and plant extracts on intestinal morphology and on leukocyte cell subsets of weaned pigs. J. Anim. Sci. 84, 2735- 2742

NRC, 1998. Nutrients Requirements of Swine. $10^{\text {th }}$ revised Edition. National Academy Press. Washington, DC

Orda J., Jamroz D., Kaźmierska M., Koźlik K., 2011. Modification of the fatty acids contents in yolk and the sensorial evaluation of egg of hens fed diets containing dried porcine blood byproducts and bone nprotein hydrolysate. In: Proceedings of Conference on Animal Nutrition. Commission of the Committee on Animal Sciences of Polish Academy of Sciences, Piechowice (Poland), pp. 98-99

Orda J., Schleicher A., Preś J., 1988. The comparison of feed value of brown livex with Fish meal, blood meal in feeding chickens for slaughter (in Polish). Rocz. Nauk. Zoot. Monogr. Rozpr. $26,365-377$ 
Owen K.Q., Nelssen J.L., Goodband R.D., Tokach M.D., Kats L.J., Friesen K.G., 1995. Added dietary methionine in starter pig diets containing spray-dried blood products. J. Anim. Sci. $73,2647-2654$

Pierce J.L., Cromwell G.L., Lindermann M.D., Russel L.E., Weaver E.M., 2005. Effects of spraydried animal plasma and immunoglobulins on performance of early weaned pigs. J. Anim. Sci. 83, 2876-2885

Rodriguez C., Blanch F., Romano V., Saborido N., Rodenas J., Polo J., 2007. Porcine immunoglobulins survival in the intestinal tract of adult dogs and cats fed dry food kibbles containing spraydried porcine plasma (SDPP) or porcine immunoglobulin concentrate(PIC). Anim. Feed Sci. Tech. 139, 201-211

Shahidi F., Naczk M., Rubin L., Diosady L., 1984. Functional properties of blood globulins. J. Food Sci. 49, 370-372

STATsoft Inc., 2005. Statistica (Data analysis software system). Version, 7.1

Tyus I.I., Nahashon J., Adefope N., Wright D., 2009. Production performance of Single Comb White Leghorn chickens fed growing diets containing blood meal and supplemental isoleucine. J. Poultry Sci. 46, 313-321

Van Dijk A.J., Everts H., Nabuurs M.J.A., Margry R.J.C.F., Beynen A.C., 2001. Growth performance of weanling pigs fed spray-dried animal plasma, a review. Livest. Prod. Sci. 68, 263-274

Vasan P., Dutta N., Mandal A.B., Sharma K., 2007. Apparent and true digestibility of amino acids of meat and bone meal and fish meal in caectomized roaster. J. Poultry Sci. 44, 396-400 